\title{
RESULTS OF TREATMENT OF CERVICAL DISCOPATHY WITH PEEK INTERBODY CAGES AT THREE LEVELS WITHOUT PLATE FIXATION
}

\author{
RESULTADOS DO TRATAMENTO DE DISCOPATIA CERVICAL COM CAGES INTERSOMÁTICOS \\ EM PEEK EM TRÊS NÍVEIS SEM FIXAÇÃO COM PLACA
}

\section{RESULTADO DEL TRATAMIENTO DE DISCOPATÍA CERVICAL CON CAJAS INTERSOMÁTICAS EN PEEK EN TRES NIVELES SIN FIJACIÓN CON PLACA}

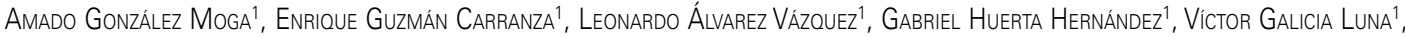 \\ Víctor Hugo Anaya Contreras' ${ }^{1}$, Abraham Isals Gómez ${ }^{1}$
}

1. ISSEMYM Ecatepec, Servicio de Cirugía de Columna, Estado de México, México.

\begin{abstract}
Objective: To present the results of treatment of patients with cervical discopathy by anterior cervical approach, discectomy and placement of a PEEK interbody cage without anterior plate fixation. Methods: Retrospective, cross-sectional study from March 2013 to March 2015. Sixteen patients with radiculopathy or clinical signs of myelopathy were included; all patients underwent cervical surgery through anterior approach, discectomy, and placement of PEEK cages on three levels. Decompression levels were determined according to the correlation between preoperative radiological and clinical findings. Results: Sixteen patients predominantly male were included, with mean age of 50 years at the onset of the condition. Ten patients had involvement of C4-C5, C5-C6, C6-C7 levels, and six patients C3-C4, C4-C5 and C5C6. Fourteen patients had cervicobrachialgia and two myelopathy. The preoperative visual analog scale average was $8 / 10$ and the average postoperative value at 6 months was 3/10. At 6 months, there was no radiological evidence of recurrence. One patient had non-fatal complications. Conclusions: The treatment of cervical discopathy by anterior approach with interbody fusion with PEEK cage on three levels, with no plate fixation seemed to be safe and effective with better long-term results in terms of pain and myelopathy. The clinical results compare favorably with other similar series and, most importantly, the complications associated with anterior fixation plate are avoided.
\end{abstract}

Keywords: Intervertebral disc Degeneration; Spinal fusion; Diskectomy.

RESUMO

Objetivo: Apresentar os resultados do tratamento de pacientes com discopatia cervical usando acesso cervical anterior, discotomia e colocação de cage intersomático em PEEK sem fixação com placa anterior. Métodos: Estudo retrospectivo, transversal no período de março de 2013 a março de 2015. Foram incluídos 16 pacientes que apresentavam radiculopatia ou sinais clínicos de mielopatia; os pacientes foram submetidos à cirurgia cervical por acesso anterior, discotomia e colocação de cages em PEEK em três níveis. Os níveis de descompressão foram determinados de acordo com a correlação entre os achados radiológicos e clínicos pré-operatórios. Resultados: Foram incluídos 16 pacientes predominantemente do sexo masculino, com média de idade de 50 anos à apresentação da afecção, sendo 10 com envo/vimento dos níveis C4-C5, C5-C6 e C6-C7 e 6 pacientes com envolvimento dos níveis C3-C4, C5-C4 e C5-C6. Catorze pacientes tinham cenvicobraquialgia e 2 mielopatia. A escala visual analógica pré-operatória média foi 8/10 e o valor médio pós-operatório aos 6 meses foi 3/10. Aos 6 meses, não se encontrou evidência radiológica de recidiva. Um paciente teve complicações não fatais. Conclusões: O tratamento de discopatia cervical por acesso anterior por fusão intersomática com cage em PEEK em três níveis, sem fixação com placa parece ser seguro e eficaz, com melhores resultados a longo prazo em termos de dor e mielopatia. Os resultados clínicos são favoráveis quando comparados com outras séries semelhantes e, o mais importante, o procedimento evitou as complicações associadas à fixação anterior com placa.

Descritores: Degeneração do disco intervertebral; Fusão vertebral; Discotomia.

\section{RESUMEN}

Objetivo: Dar a conocer los resultados del manejo del paciente con discopatía cervical utilizando abordaje cervical anterior, discectomía y colocación de caja intersomática en PEEK sin fijación con placa anterior. Método: Se realizó un estudio retrospectivo, transversal, durante el periodo de marzo de 2013 a marzo de 2015. Se incluyeron 16 pacientes que se presentaron con radiculopatía o signos clínicos de mielopatía; fueron sometidos a cirugía cervical por abordaje anterior, discectomía y colocación de cajas en PEEK en tres niveles. Los niveles de descompresión se determinaron de acuerdo a la correlación entre los hallazgos radiológicos y clínicos preoperatorios. Resultados: Dieciséis pacientes con predominio del sexo masculino, con edad media de 50 años al inicio de la enfermedad, con 10 pacientes con afección en los niveles C4-C5, C5-C6, C6-C7 y 6 en los niveles C3-C4, C4-C5 y C5-C6. Catorce tenían cervicobraquialgia y 2 mielopatía. El promedio de la escala visual análoga prequirúrgica fue 8/10 y el valor postoperatorio promedio a los 6 meses fue 3/10. A los 6 meses, no hubo evidencia radiológica de reincidencia. Un paciente tuvo complicaciones no fatales. Conclusiones: El manejo de discopatía cervical con acceso anterior mediante fusión intersomática con caja en PEEK en tres niveles sin fijación con placa parece ser segura y eficaz con una mejoría en los resultados a largo plazo tanto del dolor y la mielopatía. Los resultados clínicos se comparan favorablemente con otras series similares y, lo más importante, esta técnica evitó las complicaciones asociadas con la fijación anterior con placa.

Descriptores: Degeneración del disco intervertebral; Fusión vertebral; Discectomía. 


\section{INTRODUCTION}

Degenerative changes to the normal anatomy associated with nerve root compression can lead to the clinical syndrome of cervical radiculopathy. The region mostly affected is around the neuroforamen, from where the nerve roots exit, which is susceptible to degenerative changes such as the formation of osteophytes or disc herniations, leading to foraminal stenosis. As the cervical spine ages, biomechanical changes are known to occur in the intervertebral disc, resulting in dehydration and decreased number of chondrocytes. There are also changes in the concentrations of proteoglycan and collagen, and keratin sulfate and chondroitin sulfate. This can lead to debilitation of the fibers of the annular disc and disc herniation. There may also be a decrease in height with disc desiccation, leading to apposition around the intervertebral bodies, resulting in stenosis of the intervertebral foramen or neuroforamen. Changes in the strength of the joint facets or in the uncinate processes can result in increased mobility and osteophytes development and stenosis. These changes can lead to changes in the biomechanics of the spine and changes in cervical lordosis. ${ }^{1,2}$ Herniated cervical discs are more prevalent in males, with a maximum incidence in the third and fourth decades of life. Ninety-five percent of cervical disc lesions occur in the zone of greatest mobility, i.e. the $5^{\text {th }}$ and $6^{\text {th }}$ spaces (C5-C6 and C6-C7). The natural history of cervical disc disease shows improvement of $75 \%$ with conservative treatment. However, the remaining patients do not present good outcomes, and may be candidates for surgical treatment. Cases of myelopathy have a less predictable clinical course with a tendency towards progressive deterioration with short periods of temporary remission. Surgical management of these patients should therefore be considered. 3,4 The anterior approach to the subaxial spine was first described by Smith and Robinson and Cloward at end of the 1950s. They reported successful discectomy and anterior cervical fusion with autologous bone graft from the iliac crest in treating neural compression caused by osteophytes and disc material. Bohlman later modified this technique by introducing the trimming of the vertebral plates, which improved the fusion rates, as well as the functional results. The purpose of performing a disectomy and anterior cervical fusion is to remove the disc and osteophytes that are causing the problem and obtain a solid interbody arthrodesis. ${ }^{5-7}$

\section{METHOD}

A retrospective, transversal study was conducted in the Spine Surgery Service of the ISSEMYM Ecatepec Medical Center from March 2013 to March 2015. Sixteen patients were included, with degenerative cervical disc disease affecting three levels, which were clinically diagnosed, and confirmed by x-rays in static and dynamic views, with magnetic resonance imaging of the cervical spine, and electromyography, which identified the affected levels to be surgically treated. The variables analyzed were sex, age, levels affected, days of hospitalization, complications, and pre- and postoperative pain according to the analog visual scale; the patients were evaluated postoperatively and at 6 months, clinically and radiologically (the institution does not require approval by an ethics committee for the work presented).

\section{The surgical technique}

An oblique incision was made in the anterior cervical region on the left side. The transverse incision was made from the skin to the cutaneous muscle of the neck (platysma), conducting a blunt dissection towards the superficial fascia of the neck to reach the sternocleidomastoid, which is dissected at its medial border. The trachea, the esophagus, and the thyroid are displaced medially. The blunt dissection continues through the middle layer of the cervical fascia up to the prevertebral fascia, which is cut and dissected subperiosteally in lateral direction right to left up to the large muscles of the neck. A Caspar cervical retractor is inserted, and a jelco type needle is placed in the level to confirm with the image intensifier. The distraction of the vertebral spaces is performed using claw retractors in the vertebral bodies. Next, the intervertebral disc is cut, resected with Alligator forceps, Kerrison rongeur and curettes, as far as the posterior longitudinal ligament, where the uncinate processes, and cartilage of the terminal plate are curetted. After measuring the Peek cage, the definitive cage is inserted prior to the bone matrix and the same procedure is performed at all three levels with lateral projections using fluoroscopy, until adequate insertion is observed. (Figure 1) The bleeding is verified, and hemostasis and flushing are performed. The platysma is sutured, and the skin closed with intradermal sutures. ${ }^{8,9}$

\section{RESULTS}

Cervical degenerative disc disease is more prevalent in patients over 50 years (age range 35 to 74 years), with a higher frequency in males, with 9 cases (56\%) and in females, with 7 cases (44\%). In the 16 patients, three levels were treated: 12 (75\%) patients were affected in levels C4-C5, C5-C6, C6-C7 and four (25\%) in levels C3-C4, C4-C5, C5-C6. The main symptom was cervical pain in $88 \%$ of the cases, followed by myelopathy in $12 \%$. The average progression time of the symptoms was 40 months, ranging from 12 to 90 months. Postoperative static and dynamic x-rays, resonance and electromyography of the cervical spine were performed, resulting in 14 patients being diagnosed with multilevel cervical discopathy with disc protrusion, and 2 patients with myelopathy. The visual analog scale showed a statistically significant reduction from presurgical values compared to the postoperative value. (Figure 2) No case presented laryngeal nerve injury; there was no carotid, tracheal or esophageal lesion; aggregated neurological deficit was $0 \%$, infection $0 \%$, extrusion from the cage $0 \%$, pseudoarthrosis $0 \%$, and reoperation $0 \%$. One patient presented wound dehiscence that was favorably resolved after treatment. The average hospitalization time was 72 hours average. Patients used orthesis for 6 weeks postoperatively.

\section{DISCUSSION}

Anterior cervical discectomy with arthrodesis is a standardized procedure that is recommended for the treatment of degenerative disc and cervical spinal canal disease. Despite its usefulness, there is some controversy as to the extent to which grafts should be used for the arthrodesis, and the need to use additional plates to improve the stability; likewise, there is a lack of consensus as to the validity of the results. The use of cages in different studies has demonstrated sufficient stability to achieve cervical arthrodesis, obtaining a more solid construction that allows not only a faster and more effective arthrodesis, but also enables maintenance of the lordosis of the segment, assisting in postoperative immobilization. ${ }^{10,11}$

Zhou et al. ${ }^{12}$ presented three cases of subsidence $(20.0 \%)$ as complications of intervention to three vertebral levels without

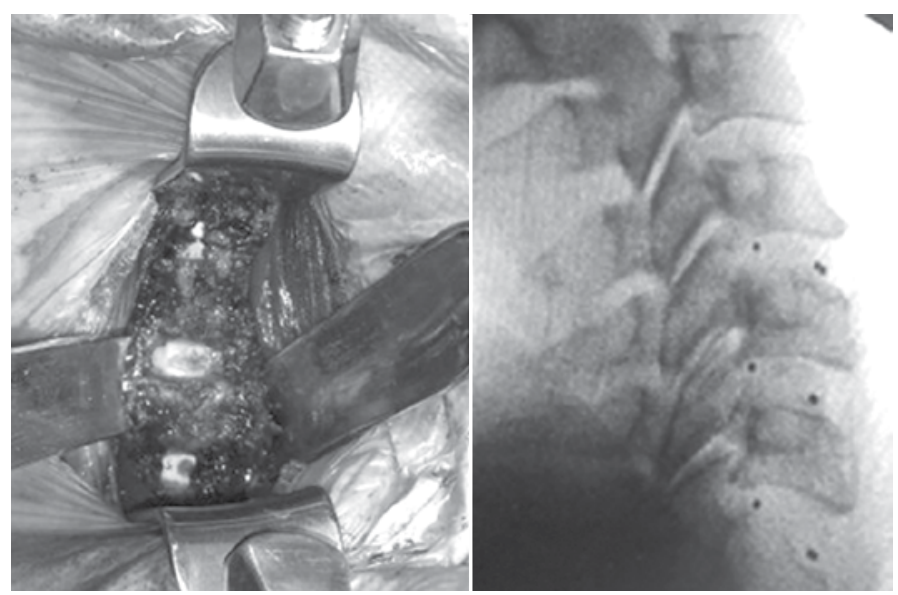

Figure 1. Transoperative image showing the placement of the interbody Peek cage in three levels and radiological control. 


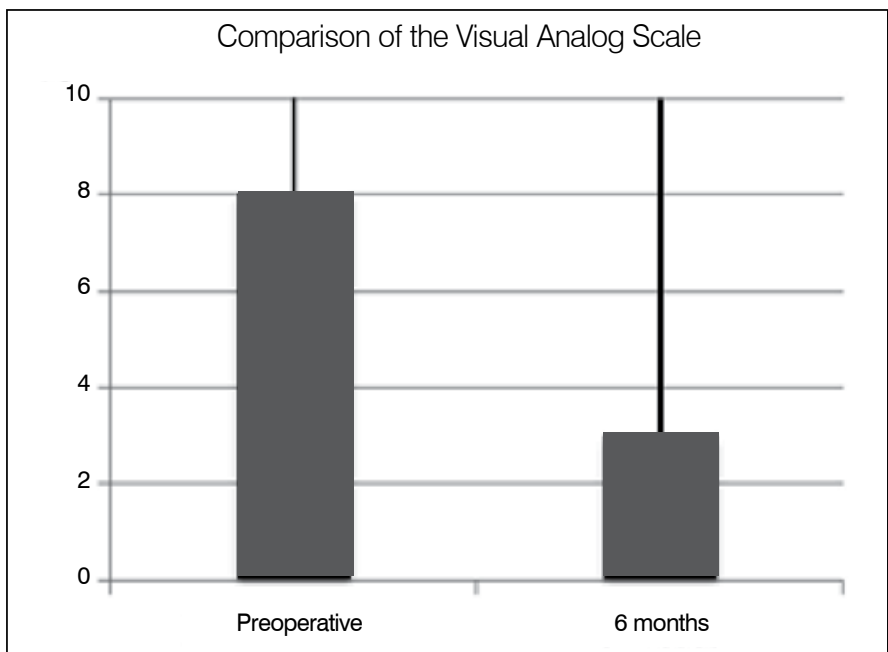

Figure 2. Comparison of the Visual Analog Scale (VAS) scores for preoperative pain and 6 months after discectomy and cervical fusion using the Peek cage in three levels without fixation with anterior plate.

anterior plate, and Liu et al. ${ }^{13}$ reported one case of sinking (4.0\%), two cases of transitory dysphagia, and one cerebrospinal fluid leak. None of these complications occurred in the present case series. Song et al..$^{14}$ reported 15 patients with anterior instrumentation of three or more levels without a plate, in their case series of 21 patients; five patients (23.8\%) presented sinking in three patients (14.3\%). However, these patients were older, with a greater degree of osteoporosis, which suggests that the anterior plate may have reduced the subsidence, therefore it would be appropriate, in this high-risk group, to insert an anterior plate. There were no complications in the remaining patients.

In a study of 16 patients by Demircan et al..$^{15} 13$ had three levels affected and 3 had four levels affected. The follow-up time was 18 to 34 months, without complications or neurological deterioration, but with significant clinical improvement. Three patients had levels of non-fusion, but no movement of the cage, and did not require reoperations within the shorter follow-up period.

Pereira et al ${ }^{16}$ reported 30 consecutive patients operated over a period of 70 months: 16 men (53.3\%) and 14 women (46.7\%), with an average age of 56.7 years at the time of the surgery (range, 43.7-70.1, and standard deviation [SD] of 7.0). Twelve patients $(40.0 \%)$ presented brachialgia, seven $(23.3 \%)$ myelopathy and $11(36.7 \%)$ a mixture of the two. The average interval between the onset of symptoms and surgery was 2.9 years (range, 1.3 to $6.7, S D$ 1.7). None of the patients had undergone prior cervical surgery. Seven patients (23.3\%) received surgery for four vertebral levels (all C3 to C7), and the other $23(76.7 \%)$, for three levels, with $19(64.4 \%)$ in C4 to C7 and four (12.3\%) in C3 to C6.

There were no surgical complications in the series within the follow-up period. There was no incidence of persistent dysphagia. Hospitalization times ranged from 1-10 days (mean 2.9, SD 2.5). The total duration of the procedure ranged from 57 to 130 minutes (mean 87.3, SD 21.5), with no statistically significant differences between the procedures on three and four levels. Six patients (20.0\%) underwent revision cervical surgery. Two (6.7\%) were due to disease of the adjacent segment in C3-C4 level. The remaining four $(13.3 \%)$ had recurrent disease in the same segments, and received posterior laminectomies and fixation. ${ }^{16}$

\section{CONCLUSIONS}

The treatment of anterior cervical discopathy by three-level interbody fusion with Peek cage without plate fixation appears to be safe and effective, resulting in an improvement in the long-term results in terms of pain and myelopathy, with shorter hospital stay and potentially short surgical procedures. The clinical results compare favorably with other similar series. Based on these results, we can conclude that the use of the interbody cage enables sufficient stability to prevent the use of an anterior plate. This helps to reduce the complications associated with the implant, such as loosening, fatigue, dysphagia, and infections. Adequate selection of patients is also important, for optimum results.

\section{ACKNOWLEDGMENTS}

We are grateful to the ISSEMYM Medical Center for allowing us to work adequately, and providing us with the resources needed for our study. Also, our patients, for placing their trust in us.

All the authors declare no potential conflicts of interest concerning this article.

AUTHORS' CONTRIBUTION: Each author contributed individually and significantly to the development of the manuscript: AGM and CGA were responsible for the conception and design of the study, LAV carried out the critical review, conception, design, analysis, and interpretation of the data. GHH and VGL performed the critical review. VHAC and AIG performed the analysis and interpretation of the data.

\section{REFERENCES}

1. Rao R. Neck pain, cervical radiculopathy, and cervical myelopathy: pathophysiology, natural history, and clinical evaluation. J Bone Joint Surg Am. 2002;84(10):1872-81.

2. Rhee JM, Yoon T, Riew KD. Cervical radiculopathy. J Am Acad Orthop Surg 2007:15(8):486-94

3. Salvi FJ, Jones JC, Weigert BJ. The assessment of cervical myelopathy. Spine J. 2006;6(Suppl 6):182S-9S

4. Baptiste DC, Fehlings MG. Pathophysiology of cervical myelopathy. Spine J. 2006:6(Suppl 6):190S-7S

5. Côté P, Cassidy JD, Carroll L. The Saskatchewan Health and Back Pain Survey. The prevalence of neck pain and related disability in Saskatchewan adults. Spine (Phila Pa 1976). 1998;23(15):1689-98.

6. Rao RD, Gourab K, David KS. Operative treatment of cervical spondylotic myelopathy. J Bone Joint Surg Am. 2006;88(7):1619-40.

7. Matz PG. Does nonoperative management play a role in the treatment of cervical spondylotic myelopathy? Spine J. 2006;6(6 Suppl):175S-181S.

8. Goldberg G, Hilibrand A. Anterior cervical discectomy and fusion. Oper Tech Orthop. 2003;13(3):188-94
9. Cloward RB. The anterior approach for removal of ruptured cervical disks. J Neurosurg 1958:15(6):602-17. ]

10. Hacker RJ, Cauthen JC, GilbertTJ, Griffith SL. A prospective randomized multicenter clinical evaluation of an anterior cervical fusion cage. Spine (Phila Pa 1976). 2000;25(20):2646-54.

11. Mobbs RJ, Rao P Chandran NK. Anterior cervical discectomy and fusion: analysis of surgical outcome with and without plating. J Clin Neurosci. 2007:14(7):639-42.

12. Zhou J, Li X, Dong J, Zhou X, Fang T, Lin H, MaY. Three-level anterior cervical discectomy and fusion with self-locking stand-alone polyetheretherketone cages. J Clin Neurosci. 2011:18(11):1505-9.

13. Liu H, Ploumis A, Li C, Yi X. Polyetheretherketone Cages Alone with Allograft for Three-Level Anterior Cervical Fusion. Neurology. 2012. 1-5.

14. Song KJ, Kim GH, Choi BY. Efficacy of PEEK cages and plate augmentation in three-level anterior cervical fusion of elderly patients. Clin Orthop Surg. 2011;3(1):9-15.

15. Demircan MN, Kutlay AM, Colak A, et al. Multilevel cervical fusion without plates, screws or autogenous iliac crest bone graft. J Clin Neurosci 2007:14:723-8.

16. Pereira EA Chari A, Hempenstall J, Leach JC, Chandran $\mathrm{H}$, Cadoux-Hudson TA. Anterior cervical discectomy plus intervertebral polyetheretherketone cage fusión over three and four levels without plating is safe and effective long-term. J Clin Neurosci. 2013;20(9):1250-5 